\title{
Prosperous Newspaper Industry May Be Heading for Decline
}

\author{
“Marketing Myopia" appears to \\ threaten newspapers with de- \\ creasing share of ecomoic support \\ in "post-industrial society."
}

- Nearly a decade ago, William A. Mindak applied the term "marketing myopia" to the newspaper industry.' The term describes firms and industries which become preoccupied with production and immediate sales and neglect marketing aspects of their products and services." Such firms enter a "selfdeceiving cycle of bountiful expansion and undetected decay" because they define their business too narrowly and insist that there is no competitive substitute for their major product.

During the past decade, the industry has made spectacular progress in production technology. And indeed, there has been "bountiful expansion" in the industry. One writer concludes that "despite the highly publicized woes of some big metropolitan dailies, most of the industry is prospering as never before." 3 This prosperity is attributed to the changing structure of the industry, primarily the trend toward one-ownership cities and the growth of "well-capitalized chains," and technological advances in production "that provide significant cost savings." "4

However, Mindak warned that for newspapers:

...the challenge of marketing will be even more crucial (than the challenge of technology). Prof. Fritz Machlup estimated

- The author is a member of the journalism faculty at the University of Oklahoma. the "knowledge industry" in the United States today to be worth some $\$ 135$ billion or nearly $30 \%$ of total national effort. Will newspapers get their proper "market share'ms

Eight years after Mindak posed this question, there are indications that the answer may be "No."

Maisel hypothesizes that the era of "bountiful expansion" for the mass media-including newspapers-may be over ${ }^{6}$ He advances "a new, three-stage theory of social change and media growth" which "challenges many of the ideas long accepted in the study of modern communication systems."

According to this theory, the third stage, now evident in the United States, is characterized by a declining growth rate for mass media and an increasing growth rate for specialized communication directed to smaller, more homogeneous audiences. If this theory is correct, the mass media will -contrary to past expectations-play a less important role in the future, and the focus of scientific attention should be shifted to specialized media. ${ }^{8}$

Maisel concludes that, "The mass media are actually shrinking in size relative to the total economy."

I William A. Mindak, "Do Newspaper Publishers Suffer from 'Marketing Myopia'? Journal I3M QLarIerLY, 42:43342 (1965).

2 Theodore Levitt, "Marketing Myopia," Harvard Business Review, July-August 1960.

'Dana L. Thomas. "Picking on the Press." Barron's, July 9. 1973, pp. 3, 17-18.

thid.

'Mindak. op. cit., p. 442.

- Richard Maisel, "The Decline of Mass Media," Public Opinion Quarterly. 37:159-70. (1973).

'thid. p. 159.

"Ibid.

Ibid. p. 168. 
TABLE 1 .

Comparative Growth of Newspaper Advertising and Gross

National Product, 1946-1970.*

Newspaper Advertising

$\begin{array}{ccccccc}\text { Year } & \begin{array}{c}\text { Millions } \\ \text { of Dollars }\end{array} & \begin{array}{c}\text { Index } \\ (1946=100)\end{array} & \begin{array}{c}\text { Percent } \\ \text { Increase }\end{array} & \begin{array}{c}\text { Billions } \\ \text { of Dollars }\end{array} & \begin{array}{c}\text { Index } \\ (1946=100)\end{array} & \begin{array}{c}\text { Percent } \\ \text { Increase }\end{array} \\ 1946 & \$ 1,158.3 & 100 & - & \$ 210.7 & 100 & - \\ 1950 & \$ 2,075.6 & 179 & 79 \% & \$ 284.6 & 135 & 35 \% \\ 1960 & \$ 3,702.8 & 320 & 78 \% & \$ 503.7 & 239 & 77 \% \\ 1970 & \$ 5,850.0 & 505 & 58 \% & \$ 976.8 & 464 & 94 \%\end{array}$

Gross National Product *Source: Economic Trends in the Daily Newspaper Business, 1946 to 1970, by Joh G. Udell,
The American Newspaper Publishers Association Foundation, New York City, December 1970.

TABLE 2

Comparative Growth of Daily Newspaper Circulation and the United States Population, 1920-1970.*

Daily Newspaper Circulation

U.S. Population

$\begin{array}{ccccc}\text { Year } & \begin{array}{c}\text { Percent } \\ \text { Increase }\end{array} & \begin{array}{c}\text { Index } \\ (1920=100)\end{array} & \begin{array}{c}\text { Percent } \\ \text { Increase }\end{array} & \begin{array}{c}\text { Index } \\ (1920=100)\end{array} \\ 1920 & - & 100 & - & 100 \\ 1930 & 42 \% & 142 & 16 \% & 116 \\ 1940 & 4 \% & 148 & 7 \% & 125 \\ 1950 & 31 \% & 194 & 14 \% & 143 \\ 1960 & 9 \% & 212 & 19 \% & 170 \\ 1970 & 5 \% & 223 & 13 \% & 192\end{array}$

"Source: U.S. Bureau of Census and "The Future of Print Media," Stock Comment 143, Merril Lynch, Fenner \& Smith, Inc., text of speech given on November 1, 1972, before the Association of National Advertisers by Industry Analyst Edward Dunleavy.

A comparison of the growth of newspaper advertising dollar volume and the GNP is shown in Table 1.

During 1946-1950, newspaper advertising grew more than twice as rapidly as the GNP. However, from 1950 to 1960 , the growth rates were practically identical, and from 1960 to 1970 , newspaper advertising growth had fallen to a rate of $58 \%$ while the GNP growth rate had risen to $94 \%$. Obviously, the growth rate for newspaper advertising has fallen sharply as a share of the total national effort.

\footnotetext{
${ }^{10}$ Maisel, op. cit.
}

The same picture emerges from a comparison of growth of daily newspaper circulation and the population. (Table 2)

Although daily newspaper circulation grew at a much faster rate than the population from 1920 to 1950 , it has grown at a much slower rate than population since 1950.

Thus the two basic indicators of growth in the daily newspaper industry-advertising and circulation-both show the same trend, which is consistent with the three-stage theory of social change and media growth presented by Maisel. ${ }^{10}$ 
New technology which has been credited with much of the recent prosperity in the newspaper industry, then, also offers the potential for what is becoming a competitor to the industry-specialized media.

And the other major source of prosperity-growth of "well-capitalized chains" and one-ownership cities-also appears to be nearing saturation. Only $2.5 \%$ of all daily newspaper cities now have two or more competing newspapers, and Thomas points out that:

In evaluating the future, it should be pointed out that a good share of past growth of many newspaper chains has been via acquisitions. However, finding a desirable newspaper at the right price is becoming increasingly difficult. In recent years, purchases have been made at 35-to-40 times earnings, and quotes continue to soar."

There appear to be at least two alternatives available to those who are in the newspaper industry and those who study mass communication. We can write off the daily newspaper as a viable medium in the "third stage, or "post-industrial society," or we can begin a serious reevaluation of the economic and social role of the daily newspaper industry.

Almost 15 years ago, Landau and Davenport appealed for more theory development in communications economics. ${ }^{12}$ They wrote:

...economists need to elaborate new theories for the media of mass communication. The laws and standards of existing theories are inadequate or inapplicable. Some of the major problems of the mass media today are centered in the economic area, a situation which emphasizes the urgent need for more research and theory development in mass communication economics ... ${ }^{13}$

And yet today, we have not responded to this appeal in any significant way. We have failed to give adequate attention to the newspaper as an industrial system. The newspaper industry apparently still lacks the ability to even identify and define its product in terms of the consumer. An example of this lack of definition of product is apparent, for example, in the industry's reaction to the recent shortage of newsprint. Some newspapers limited ad sizes, or even eliminated advertising completely. Others reduced the size of their "news hole," or began to condense news reports from full stories to summaries. Still others reduced or eliminated various features, such as weekly TV guides, comic strips, or stock market quotations. And some reduced or stopped expansion of circulation. 14

The lack of any pattern of response in reaction to reduced newsprint supplies would seem to indicate that the newspaper industry does not have a very clear picture of what its consumers want or need.

Here are a few examples of the kinds of oconomics/marketing questions the newspaper industry has yet to answer:

Product Definition. Just what is a daily newspaper? Most definitions are based on physical characteristics, such as content, size, appearance, etc. But Churchman suggests that the way to describe a product (from a systems approach) "is first by thinking about what it is for, about its functions, and not a list of items that make up its structure." 15

And if we say that a newspaper is made up of advertising and news, we must recognize that we still lack a generally acceptable definition of "news." 16

At this point, it would appear that we need to make a serious effort to really define the newspaper product in terms of the consumer. What are the functions of a newspaper in today's society?

We must begin to think in terms of the product as seen by the consumer, rather than as seen by the journalist. There is growing evidence that the consumer

"Thomas, op. cit., p. 18.

12 Edmund Landau and John Scott Davenport, "Price Anomalies of the Mase Medin," Journalism QuArtenty, 36:291-4 (1959).

"Bbid., p. 294

14"E \& P Told Newaprint Strikes May Be Settled By Sept. 1," Editor a Publisher. Aug. 25, 1973, p. II, and other ar. ticles.

is C.Weat Churchman, The Systems Approach (New York: Dell Publishing Co., 1968), p. 13.

14 L. Erwin Atwood and Gerald L. Grotta, "Socialization of New Values in Beginning Reporters," Journalsm QUARTERtY, 50:759-61 (Winter 1973). 
sees the newspaper in a very different way than the journalist sees it.

It is not surprising that journalists have a more flattering image of the press than do non-journalists, as Shaw suggests. ${ }^{17}$ However, there is evidence that journalists tend to project their "flattering image" of the press to the general public, and assume that the public shares the journalist's view that the press is somehow special in our society. For instance, Mott wrote: "This transcendent importance of news and information in a democracy is deeply felt by the reading and listening public"18

A recent pilot study indicates that the consumer may not attach such a "transcendent importance" to the press. In the study, journalists rated newspapers as significantly more important to society than other businesses. The journalists ranked newspapers significantly higher than other businesses in fulfilling their social responsibilities. They also rated newspapers as deserving greater freedom from external controls than other businesses. ${ }^{19}$

However, non-journalists did not make such distinctions between newspapers and other businesses. This raises some disturbing questions for the newspaper industry. Why would the public fail to make the same distinctions between the press and non-media businesses that journalists make? Has the newspaper industry failed to perform in such a way that the public would perceive newspapers as more important, more socially responsible, or more deserving of freedom from external controls than such businesses as food stores, banks, car manufacturers, insurance companies, etc.?

\footnotetext{
1'Eugene F. Shaw. "The Press and tis Freedom," paper presented at the Aswociation for Education in Joumaliam convention, August 1970, American Univentity, Washington, D.C.

it Frank Luther Mot, The News in Americe (Cambridge: Harvard University Prese, 1962), p. 7.

10 Gerald L. Grotta and Huing-ti Cheng, "The Pres: Something Special or Juat Another Business? unpublished paper.

rondau and Davenport, op. cit.. p. 292.

21 bid.

$2290 \%$ in Survey Receptive to ise a copy, Gallup Says," Editor A Pubtisher, April 24, 1971, p. II.

23 Edwin Menafield, Manogerial Economics and Operations Research (New York: W.W. Norton a Co., 1966), p. 52.
}

If so, we must ask where the public feels the newspaper has failed. Indeed, we must ask what the public expects from the newspaper. What is the role of the media in contemporary society, as perceived by the consumer?

Price Elasticity. The pricing of newspaper subscriptions remains purely arbitrary, as Landau and Davenport reported almost 15 years ago. 20 They stated that, "The forceful influence of this arbitration seems to be a belief that a newspaper must be sold at an insignificant price in order to have a mass appeal." 21

As a result of the arbitrary and cautious approach to pricing subscriptions, the ratio of both advertising to circulation support and advertising to editorial content have increased in recent years.

In 1961, Gallup advised newspaper publishers that the majority of their readers were receptive to 15 -cents-a-copy price. At that time, most publishers apparently believed that 5 cents a copy would be the maximum people would pay, and only recently have newspapers moved significantly toward the 15 cents price Gallup assured them would be "safe."22

As recently as 1971 , only .148 of the 1,742 daily newspapers in the United States were charging the 15 cents price. Mansfield has pointed out that:

Moat businessmen intuitively are aware of the elasticity of demand of the goods they make, although they may not have a detailed, precise estimate. Nevertheless, some firms tend to be conservative and underestimate the elasticity of demand. ${ }^{23}$

The opposite appears to be true of the newspaper industry, which indicates by its reluctance to increase subscription prices that it fears a high degree of elasticity of demand. Yet, all of the available evidence indicates a low degree of elasticity, which means subscription prices could increase considerably without a corresponding decrease in demand.

Cross-Elasticity. If the newspaper industry is to reverse the trend toward a decreasing share of both the GNP and media expenditures, it must begin to 
look more closely at relevant competitors, as viewed by the consumer.

McCombs has advanced the "constancy hypothesis" to explain the position of the mass media in the marketplace. ${ }^{24}$ This hypothesis states that the amount of money spent on the mass media is a relatively constant proportion of the total GNP, but with a moderately declining trend across time.

Under the McCombs hypothesis, as new mass media arise, the public diverts economic support from the old media to support the new. McCombs concludes:

The Principle of Relative Constancy describes a major economic constraint on the growth of the media in the marketplace over at least the past 40 years. But even with continued economic growth, mass media consumption may reach asymptote, with the ultimate constraint likely to be scarcity of time. For the immediate decades ahead, these two factors-time and money-will jointly constrain the growth of mass media in the marketplace. 25

If the newspaper is to survive in the decades ahead, it must do so on the basis of offering the consumer a product which fulfills the needs of the consumer. And again, this requires the industry to define its product in terms of the consumer. The newspaper industry must finally begin to adopt a consumer-oriented marketing approach to its product.

Mindak quotes Drucker about the railroads' failure to understand their marketing role:

As late as 1950 the American railroads refused to accept that the passenger automobile, truck and airplane were here to stay. They considered it unthinkable that railroads could be displaced as the backbone of the country's transportation system. ${ }^{26}$

Drucker then explains how once railroads recognized the new competition, "they were able to concentrate on what they could do best - the long-distance hauling of bulk commodities such as automobiles, grain, coal and iron ore."27

Newspaper publishers must likewise begin to look at the new media in terms of relevant competition and search for the aspects of their product that they can do best. If, indeed, there are such aspects, newspapers will have to identify them and concentrate on them. Only then will the newspaper have a chance of surviving as a viable economic enterprise in the future.

Such an undertaking will require much closer cooperation between people in the newspaper industry and those in academe. If we fail to make a major effort to begin such an undertaking, those who are in the newspaper industry may in the future find themselves in the same position as buggy whip manufacturers. And those of us who study the newspaper may become archeologists, looking at a social institution which failed to survive in a changing environment.

Mindak cites past fears that the newspaper was a "dying medium." He adds that:

History has proved most of these gloomy prognosticators wrong IF (and this is a big if) the media reacted intelligently and quickly to their changing environment. ${ }^{28}$

As the newspaper industry makes great strides in solving problems of production through new technology, it must launch immediately at least an equally concentrated effort to solve problems such as those posed in this article. It must begin to react intelligently and quickly to the changing economic and social environment of which it is a part.

\footnotetext{
24axwell E. McCombe, "Mass Media in the Marketplace," Journalism Monographs. No. 24, August 1972.

is $/$ bid., pp. 62-3.

26 Mindak, op. cit. p. 433.

${ }^{27}$ lbid.

Ibid., p. 442.
}

- Objectivity is unattainable because, paradoxically, we can only approach objectivity by interpretation-evaluating and selecting from the mass of information those facets that convey the reality as we perceive it.-Howard C.E. JoHNSON in Better Editing 